\title{
ВИКОРИСТАННЯ ЕЛЕМЕНТІВ ШТУЧНОГО ІНТЕЛЕКТУ В ЕКСПЕРТНІЙ СИСТЕМІ ДЛЯ ДІАГНОСТУВАННЯ ГЕНЕТИЧНИХ ВІДХИЛЕНЬ
}

\author{
В. 3. Стецюк, Л. Ю. Бабінцева ${ }^{1}$, Ю. М. Чиж, \\ О. Д. Фіногенов, Н. В. Самоненко, І. П. Муха \\ Національний технічний університет України \\ «Київський політехнічний інститут імені Ігоря Сікорського» \\ ${ }^{1}$ Національний університет охорони здоров'я України імені П. Л. Шупика
}

\begin{abstract}
У статті описано вирішення проблеми представлення знань за допомогою семантичної мережі при розробці експертної системи діагностування генетичних відхилень. Система призначена, в першу чергу, для спрощення процесу встановлення діагнозу, зменшення ймовірності лікарської помилки при діагностуванні захворювання, ведення обліку та реєстрації пацієнтів. «Експертна система для діагностування генетичних відхилень» розроблена для допомоги та автоматизації діяльності працівників відділення медичної генетики.
\end{abstract}

Ключові слова: експертна система, семантична мережа, база знань, штучний інтелект, генетичні відхилення.

\section{USING ELEMENTS OF ARTIFICIAL INTELLIGENCE IN AN EXPERT SYSTEM FOR DIAGNOSING GENETIC DISORDERS}

\author{
V. Z. Stetsyuk, L. Yu. Babintseva ${ }^{1}$, Yu. M. Chyzh, \\ O. D. Finogenov, N. V. Samonenko, I. P. Muha \\ National Technical University of Ukraine «Igor Sikorsky Kyiv Polytechnic Institute» \\ ${ }^{1}$ Shupyk National Healthcare University of Ukraine
}

\begin{abstract}
Background. Knowledge representation and reasoning is the field of artificial intelligence dedicated to representing information about the world in a form that a computer system can utilize to solve complex tasks such as diagnosing a medical condition or having a dialog in a natural language. A semantic network, or frame network is a knowledge base that represents semantic relations between concepts in a network. This is often used as a form of knowledge representation. Expert systems are a class of computer programs that offer advice, analyze, classify, advise, and diagnose.

After studying and analyzing the problems of the field of genetics, we decided to develop an expert system, which with the help of the available knowledge base will be able to determine and clarify the diagnosis, provide advice and, if necessary, appoint additional examinations. The purpose of this work is to develop a computer software "Expert system for diagnosing genetic disorders".

Materials and methods. The research material is the work of a geneticist who diagnoses and prescribes treatment to patients, maintains medical records.

Results. The result of the research of the work of employees of the department of medical genetics of Children's Hospital and the analysis of the specifics of the implementation of medical expert systems is an expert system that optimizes the work of department staff. The software product "Expert system for diagnosing genetic disorders" is installed on any number of computers in the department.

The system implements the following functions: work in two modes: the mode of knowledge acquisition and the mode of consultation; establishing the correspondence of symptoms, further treatment and diagnoses in the mode of acquiring knowledge; diagnosis of the patient when choosing symptoms from a list; providing referrals for clinical trials to clarify the diagnosis; providing a treatment protocol for the diagnosis.

Conclusions. The main result of the work is a system that optimizes the work of doctors and staff of the department of medical genetics of Children's Hospital.
\end{abstract}

Key words: expert system, semantic network, knowledge base, artificial intelligence, genetic disorders.

(с) В. З. Стецюк, Л. Ю. Бабінцева, Ю. М. Чиж, О. Д. Фіногенов, Н. В. Самоненко, І. П. Муха 


\title{
ИСПОЛЬЗОВАНИЕ ЭЛЕМЕНТОВ ИСКУССТВЕННОГО ИНТЕЛЛЕКТА В ЭКСПЕРТНОЙ СИСТЕМЕ ДЛЯ ДИАГНОСТИКИ ГЕНЕТИЧЕСКИХ НАРУШЕНИЙ
}

\author{
В. З. Стецюк, Л. Ю. Бабинцева ${ }^{1}$, Ю. М. Чиж, \\ О. Д. Финогенов, Н. В. Самоненко, И. П. Муха \\ Национальный технический университет Украины \\ «Киевский политехнический институт имени Игоря Сикорского» \\ ${ }^{1}$ Национальный университет здравоохранения Украины имени П. Л. Шупика
}

\begin{abstract}
В статье описано решение проблемы представления знаний с помощью семантической сети при разработке экспертной системы диагностики генетических отклонений. Система предназначена, в первую очередь, для упрощения процесса установления диагноза, уменьшения вероятности врачебной ошибки при диагностировании заболевания, ведения учета и регистрации пациентов. «Экспертная система для диагностики генетических отклонений» разработана для помощи и автоматизации определенной деятельности сотрудников отделения медицинской генетики.
\end{abstract}

Ключевые слова: экспертная система, семантическая сеть, база знаний, искусственный интеллект, генетические отклонения.

Вступ. Відомо, що основою експертної системи є знання. Однією з функцій експертної системи являється представлення знань, у той же час саме представлення знань є одним із важливих завдань штучного інтелекту. Говорячи про представлення знань із точки зору штучного інтелекту, слід зазначити, що метою експертної системи буде навчитися застосовувати, видобувати та обробляти знання таким чином, щоб досягати подібності з людським інтелектом. Дослідники штучного інтелекту використовують теорії подання знань 3 когнітології, оскільки методи збереження інформації подібні до тих, що існують у мозку людини. Проблема представлення знань $є$ однією з найважливіших, характерних для систем, що базуються на знаннях. Зрозуміло, що форма представлення знань впливає на характеристики та властивості системи, тому головним завданням побудови систем, що базуються на знаннях, $є$ вибір форми їх представлення (мови, методу, моделі) [2].

Нагадаємо, що експертна система, як правило, містить три типи знань: структуровані знання про предметну область, структуровані динамічні знання та робочі знання. Представлення знань - це множина синтаксичних і семантичних угод, що роблять можливим формальне вираження знань про предметну область у комп’ютерно інтерпретованій формі. Для представлення знань у сучасних експертних системах використовуються різноманітні способи, наприклад, правила, семантичні сітки, фрейми. А найбільш поширеними моделями представлення знань вважають такі: логічні, продукційні, фреймові, семантичні мережі. Останні були найбільш цікавими для вирішення завдань даного дослідження, оскільки дають можливість подавати знання в моделі представлення знань разом із способами їх інтерпретації.

Семантична мережа відображає семантику предметної області у вигляді понять і відносин між ними. Зображується у вигляді графу, вершини якого відповідають об’єктам або поняттям, а дуги, що з'єднують вершини, визначають зв'язки між ними. Зв'язки можуть бути різних типів: «є», «є частиною», «містить» тощо. Зауважимо, що створення семантичних мереж починається з опису схеми даних, далі задаються конкретні об’єкти, що відповідають зв'язкам.

У семантичних мережах продукційні правила подано найбільш наближено до процесу мислення людини, тому вони дозволяють: додавати або видаляти фрагменти мереж; додавати або видаляти зв'язки чи вершини; перевіряти приналежність певного елемента мережі; знаходити елементи спільні для двох і більше мереж.

Поглиблене вивчення проблематики сфери діяльності професії лікаря-генетика та реалізація експертної системи для діагностування генетичних відхилень [1] визначили необхідність додавання до цієї експертної системи елементів штучного інтелекту.

Мета роботи: представлення комп'ютерного програмного комплексу «Експертна система для діагностування генетичних відхилень» із елементами штучного інтелекту. 
Матеріал та методи дослідження. Для розроблення програмного продукту використовувалась мова програмування $\mathrm{C}++$ та середовище програмування Embarcadero C++ XE7. Для збереження даних розроблено відповідну реляційну локальну базу даних формату SQL Server. Для реалізації роботи з базою даних обрано Microsoft SQL Server 2012 Express. Матеріалом дослідження стала база даних електронної медичної облікової документації відділення медичної генетики дитячої лікарні «ОХМАТДИТ», способи ії оброблення та формування результату за наявними параметрами (з використанням основних елементів архітектури Microsoft SQL Server).

Результати та їх обговорення. Використання ієрархічної семантичної мережі для оброблення інформації стосовно конкретної предметної області можна розглянути на прикладі моделі семантичної мережі для медичної діагностики. Структура даної семантичної мережі може бути різною. У запропонованій моделі вершини графу — такі об'єкти: симптоми захворювання, синдроми (об'єднані якоюнебудь характеристикою групи симптомів, що визначають можливі захворювання), захворювання (факт існування у пацієнта патологічного процесу), результати досліджень і діагнози. Крім того, в силу специфіки предметної області, наявності класифікації захворювань і симптомів, кожна вершина може мати ієрархічну структуру. Класифікації захворювань або діагнозів мають вигляд дерева та розміщуються в ієрархічну вершину семантичної мережі.

У мережі наявні різні види n-арних зв'язків, відношень, що пов'язують більше, ніж два поняття. Основний вид зв'язку між вершинами графу для даної моделі - «є ознакою». Наприклад, симптом ангіокератоми - $є$ ознакою - захворювання бетаманнозидоз. Отже, зв'язок «є ознакою» - підлеглий зв'язку між симптомами та захворюваннями, симптомами та синдромами, синдромами та захворюваннями, захворюваннями та діагнозом. Для позначення обернених відношень використовується зв’язок «має ознаку». Наприклад, захворювання альфа-маннозидоз - має ознаку — панцитопенія. Логічне відношення «I» — зв'язок між вершинами одного виду. Всередині ієрархії також існують зв’язки, що іменуються «елемент класу».
Тобто, в ієрархічній семантичній мережі існує можливість ділити мережу на підмережі та встановлювати зв'язки не тільки між вершинами, а й між фрагментами мережі. Різноманітні фрагменти мережі впорядковані у вигляді дерева, де вершини — це окремі підмережі, а дуги — зв'язки «видимості». Це дозволяє значно скоротити час пошуку рішення по мережі, не включаючи в пошук підмережі, що не пов’язані відношеннями видимості.

Семантична мережа працює за допомогою правил, що управляють переходами між вершинами по дугах мережі, пов'язуючи умови та дії. Правила об'єднують елементи мережі, використовуючи типи зв'язків між ними так, що вони будують логічні ланцюжки тверджень. Наприклад, правило звучить «Якщо у пацієнта є скелетні деформації, то можливо у нього муколіпідоз ІІ типу». Правила складаються зі зв'язку «якщо-то» з однією або декількома умовами, висновку (декількох висновків) та їхньої ймовірності. Нижче наведено спосіб представлення правил у запропонованій моделі знань:

$<$ правило $>::=($ ЯКЩО <умова >

ТО <імовірність $><$ дія $>$ )

$<$ умова $>::=<$ твердження $>$

$<$ твердження $>::=<$ логічне твердження $>$ |

$<$ описове твердження >

$<$ логічне твердження> :: $=\left(\{\mathrm{I}<\text { твердження }>\}^{*}\right) \mid$

$\left(\{\text { АБО }<\text { твердження }>\}^{*}\right) \mid\left(\right.$ HE $\left.\{<\text { твердження }>\}^{*}\right)$ $<$ дія $>:=<$ описове твердження>

Для врахування невизначеності використовується коефіцієнт визначеності тверджень, що доцільно обчислювати за правилами нечіткої логіки. При роботі з мережею він може зазначатись як для вхідних даних, так і для виводу тверджень. Наприклад, «Якщо у пацієнта ангеакератоми, то можливо захворювання - фукозидоз». За допомогою нечітких множин найповніше можна визначити ступінь прояву симптомів, що суттєво впливає на вихідні дані, а саме, постановку діагнозу, уточнюючи його та відкидаючи варіанти, отримані при пошуку, що не підходять.

Така семантична мережа дозволяє здійснити ефективний і швидкий пошук, змістовний аналіз навіть великих об’ємів медичної інформації.

Нагадаємо, що в експертній системі виділено два основні режими: режим набуття знань і режим вирішення завдання (у тому числі, режим 
консультації або режим використання). У режимі набуття знань спілкування з експертною системою здійснює експерт (вважаємо користувача системи, який задає відповідність симптоматики і діагнозів). У режимі консультацій спілкування з експертною системою здійснює кінцевий користувач, якого цікавить результат або спосіб його одержання [1].

В даній експертній системі реалізовано не тільки виконання алгоритмом послідовності операцій, але й попереднє його формування, тобто функція самонавчання.

Розроблена експертна система, керуючись своєю базою знань, пропонує список діагнозів, що включають у себе вказані симптоми (після відмітки кожного наступного симптому список можливих діагнозів буде скорочуватись). Якщо після відмітки всіх встановлених симптомів у цьому списку залишиться лиш один діагноз, він вважатиметься встановленим основним діагнозом захворювання. Якщо таких діагнозів буде декілька, то система запропонує уточнити діагноз шляхом призначення додаткового обстеження. Якщо огляд пацієнта проводить користувач із рівнем доступу «Експерт», то експертна система дозволить йому обрати діагноз, що неоднозначно визначається за переліком встановленої симптоматики, та запам'ятає цей вибір. У випадку багатократного повтору встановлення користувачами з рівнем доступу «Експерт» даного діагнозу при даній симптоматиці, експертною системою буде внесено зміни в свою базу знань (змінено набір симптомів для діагностування захворювання).

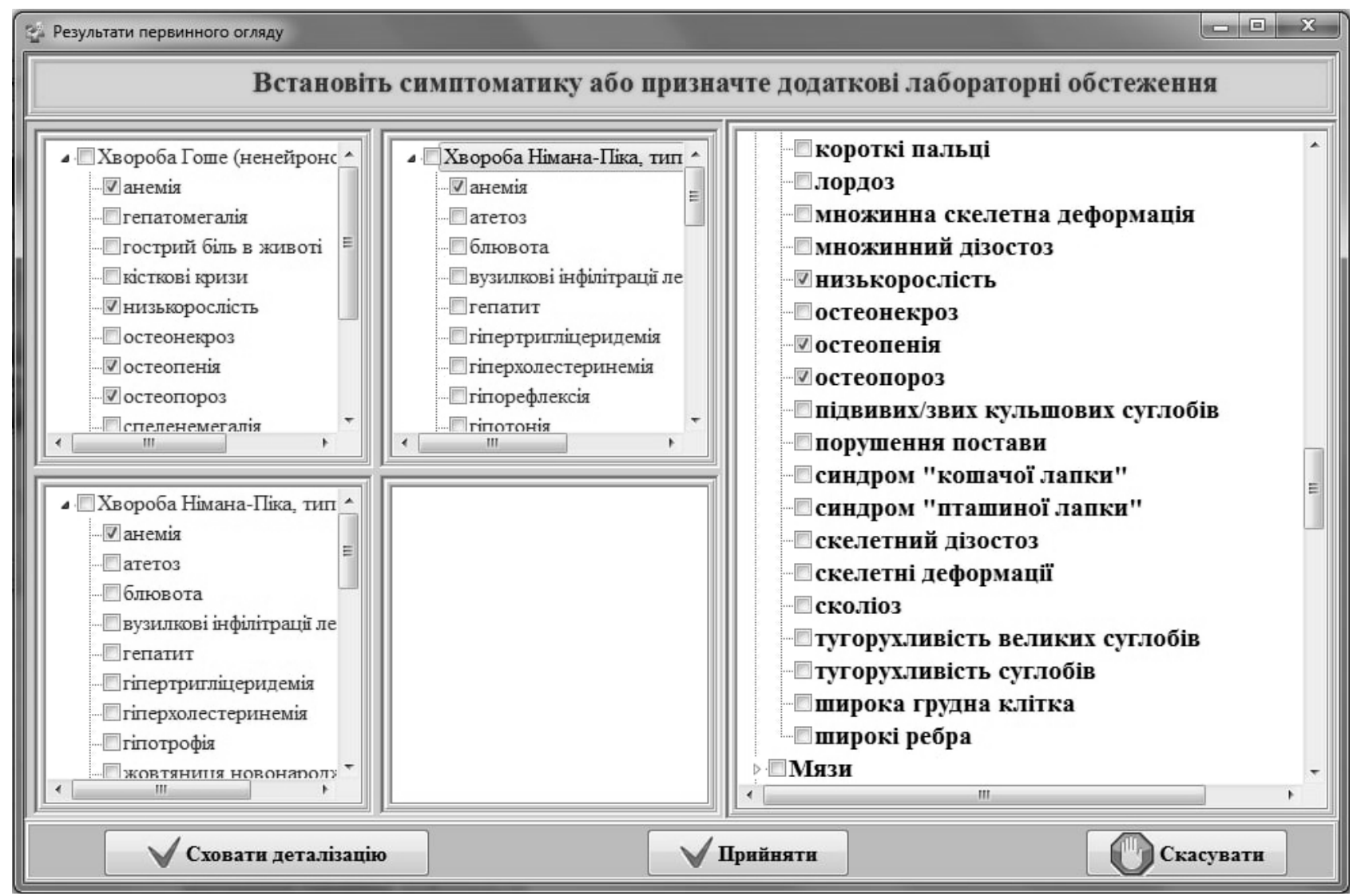

Рис. 1. Елементи експертної системи для діагностування генетичних відхилень

Висновки. Представлено програмний продукт «Експертна система для діагностування генетичних відхилень», що після поглибленого вивчення проблематики сфери діяльності професії лікарягенетика та аналізу впровадження експертної системи доповнено елементами штучного інтелекту. Представлення знань у даній експертній системі реалізовано за допомогою семантичної мережі. 


\section{Література.}

1. Експертна система для діагностування генетичних відхилень / В. З. Стецюк, Л. Ю. Бабінцева, Ю. М. Чиж та ін. // Медична інформатика та інженерія. - 2020. - № 3. - С. 78-83.

2. Життя 3.0. Доба штучного інтелекту / Макс Тегмарк ; пер. $з$ англ. 3. Корабліна. - К.: Наш формат, 2019. - 428 с.

3. Семантична мережа. [Електронний ресурс]. - Режим доступу: https://goo-gl.su/YdeRJ.

4. Обработка web-информации на основе модели представления знаний. [Електронний ресурс]. - Режим доступу: https://goo-gl.su/oavP.

5. Експертні системи в медицині : навч. посібник для студентів вищих навчальних закладів / Синекоп Ю. С., Продеус А. М., Швець Є. Я. та ін. - Запоріжжя, 2014. - 332 с.

\section{References.}

1. Stetsyuk, V. Z., Babintseva, L. Yu., Chyzh, Yu. M. et al. (2020). Expert system for diagnosing genetic disorders. Medical Informatics and Engineering, 3, 78-83. [In Ukrainian].

2. Tagmark M. (2019). Life 3.0. The Age of Artificial Intelligence (lane. from English Z. Korablin). Kyiv: Our format. [In Ukrainian].

3. Semantic network. URL: https://goo-gl.su/YdeRJ. [In Ukrainian].

4. Processing web-information based on the knowledge representation model. URL: https:/goo-gl.su/oavP. [In Russian].

5. Synekop, Y. S., Prodeus, A. M., Shvets, E.Y. et al. (2014). Expert systems in medicine: a textbook for students of higher educational institutions. Zaporizhzhia, 2014. [In Ukrainian]. 